\title{
FRACTIONATION OF CARBOHYDRATES AND PROTEINS IN TIFTON 85 BERMUDAGRASS HAY AT DIFFERENT CUTTING LEVELS AND STORAGE TIME
}

\author{
FRACIONAMENTO DE CARBOIDRATOS E PROTEÍNA EM FENO DE CAPIM \\ TIFTON 85 SOB DUAS ALTURAS DE CORTE E TEMPOS DE ARMAZENAMENTO
}

\author{
Samantha Mariana Monteiro SUNAHARA'; ${ }^{1}$ Marcela Abbado NERES'; \\ Jaqueline Rocha Wobeto SARTO² ${ }^{2}$ Caroline Daiane NATH' ${ }^{1}$ Kácia Carine SCHEIDT $^{3}$; \\ Maximiliane Alavarse ZAMBOM ${ }^{1}$
}

1. Universidade Estadual do Oeste do Paraná - UNIOESTE, Mal. Cândido Rondon, PR, Brasil. samanthasunahara@ yahoo.com.br; 2. Universidade Estadual Paulista Júlio de Mesquita Filho, UNESP, Botucatu, SP, Brasil; 3. Universidade Estadual de Maringá, UEM Maringá, PR, Brasil.

\begin{abstract}
This study aimed to evaluate the fractionation of carbohydrates and protein of grass hay Tifton 85 bermudagrass under two cutting heights in relation to ground level $(0.04$ and $0.08 \mathrm{~m})$ during 120 days of storage. Samples were collected in the baling and hay stored in shed at 30, 60, 90 and 120 days of storage, after, it was subjected to laboratory procedures, in which the levels of soluble carbohydrates were determined, carbohydrate fractionation and protein fractionation. The results were studied in a randomized complete block design with split plot with two treatments allocated the plots: cutting height of 0.04 to $0.08 \mathrm{~m}$ from the ground and five times in the subplots: baling, $30,60,90$ and 120 days of storage hay, with five repetitions. The soluble carbohydrate concentration hay responded in a quadratic manner to the storage time for cutting heights of 0.04 and $0.08 \mathrm{~m}$ above soil level; minimum values of 11.53 and $10.70 \mathrm{~g}$ $\mathrm{kg}^{-1}$ of DM were estimated for 93.44 and 91.16 storage days, respectively. The carbohydrate fraction A + B1 responded negatively linear to periods of storage evaluated in both cutting heights. The contents of the carbohydrate fraction B2 and proteins $\mathrm{A}$ and $\mathrm{C}$ exhibited a positive linear response to storage time for a cutting height of $0.04 \mathrm{~m}$ and a quadratic effect for hay cutting height at $0.08 \mathrm{~m}$ above soil level, with an opposite behavior for both cutting heights for the B1 protein levels and $\mathrm{C}$ carbohydrate fraction. The B2 fraction showed a negative linear response as a function of storage time, with a reduction in the fraction of 0.09 and 0.11 percentage units for each day of storage, for hay cutting height of 0.04 and 0.08 $\mathrm{m}$, respectively. The B3 fraction responded quadratically to the storage time, the two studied cutting heights. The storage of Tifton 85 hay cut at $0.04 \mathrm{~m}$ above soil level for 120 days leads to a decrease in fractions of rapid ruminal degradation and increase of the indigestible fraction in carbohydrate and protein fractions. Based on the results obtained it is recommended the cutting of the Tifton 85 bermuda grass forage to produce hay at $0.08 \mathrm{~m}$ and its storage up to 30 days provided that under ideal conditions.
\end{abstract}

KEYWORDS: Forage conservation. Haymaking. Nitrogen compounds. Starch.

\section{INTRODUCTION}

Food is responsible for most animal production costs. Therefore, for the best productivity, feed formulations must be carefully adjusted. As such, it is important to understand the behavior of food in the digestive tract (PEREIRA et al., 2007). To estimate animal performance more accurately and improve nutrient efficiency, all information about an animal's food, including carbohydrate and protein fractions, is required.

With the Cornell Net Carbohydrate and Protein System (CNCPS), foods were subdivided by their chemical and physical characteristics, ruminal degradation, and post-rumen digestibility (SNIFFEN et al., 1992). Using the estimation of these fractions in the gastrointestinal tract, it is possible to adjust the feed supply, with the goal of maximum efficiency of microbial protein synthesis.
With the best formulated diets, it is possible to reduce energy and nitrogen losses caused by ruminal fermentation and to maximize the synchronization of nitrogen and carbohydrate degradation in the rumen (SILVA, SILVA, 2013).

Milk production in western Parana is based on the use of tropical grasses in pastures or conserved in the form of silage or hay. The use of forage preserved in the form of hay is a very common practice used by farmers as an alternative to solve the problem of the seasonality of fodder, and to allow the best use of the surplus; however, the storage of forage for long periods of time may cause changes in nutritional value (CASTAGNARA et al., 2011) and the growth of undesirable microorganisms that influence the chemical composition, intake, and digestibility of forage. Nevertheless, Pasqualotto et al. (2015) did not observe changes in the chemical composition of 
Tifton 85 bermudagrass hay stored up to 90 days in a covered shed.

The cutting height of the forage for haying can influence the nutritional value of the forage by affecting dry matter production, since cutting heights closer to the ground increase mass production, but these also include senescent parts that contribute to reduced nutritional value of the hay. Moreover, higher cuts increase the nutritional value of forage because of the higher percentage of green leaf blades captured, but reduce the dry matter yield per unit area. The hay conditioners currently used to cut forage for hay follow the irregularities of the terrain and the adjustment of the cutting height is based on the extension or retraction of the arm of the machine when coupled to a tractor. The technology available today in the mowers allows uniform cuttings that accompany the roughness of the terrain.

The objective of this study was to evaluate the carbohydrate and protein fractionation of Tifton 85 bermudagrass hay (Cynodon spp. cv. Tifton 85) under two cutting heights in relation to the soil level $(0.04$ and $0.08 \mathrm{~m})$ during 120 days of storage in a closed shed. We test the following hypothesis: cutting height at $0.04 \mathrm{~m}$ from the ground will produce a lower quality hay at $0.08 \mathrm{~m}$ and storage up to 90 days will not cause significant decreases in the more soluble fractions of carbohydrates and proteins.

\section{MATERIAL AND METHODS}

The experiment was conducted in Marechal Cândido Rondon, Paraná, Brazil under field conditions at a farm dedicated to the production of hay, with a total area of hay production of 20 ha. The farm was located at latitude $24^{\circ} 32^{\prime} 49.7^{\prime \prime} \mathrm{S}$, longitude $54^{\circ} 01^{\prime} 46.4^{\prime \prime} \mathrm{O}$ and altitude of $392 \mathrm{~m}$. The local climate, classified according to Köppen, is of type Cfa, subtropical, with rains well distributed throughout the year and hot summers. The climatic data for the experimental period are shown in Figure 1.

Precipitation (mm)

$\longrightarrow \mathrm{T} \operatorname{Max}\left({ }^{\circ} \mathrm{C}\right)$

----- T Mín $\left({ }^{\circ} \mathrm{C}\right) \quad \longrightarrow$ RH (\%)

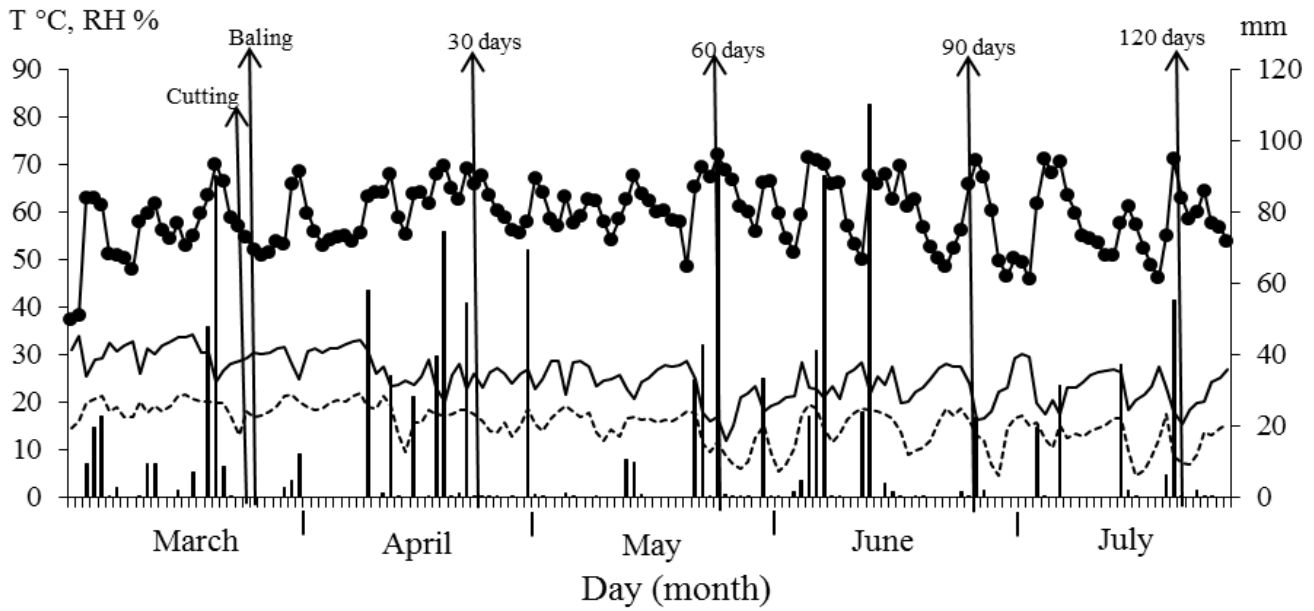

Figure 1. Maximum and minimum air temperature $\left({ }^{\circ} \mathrm{C}\right)$, mean relative air humidity $(\%)$ and rainfall $(\mathrm{mm})$ during the months of cutting, baling, and storage of hay.

The soil of the experimental area is classified as Eutroferric Red Latosol (EMBRAPA, 2013), or Rhodic Acrudox (SOIL SURVEY STAFF, 2010), with $650 \mathrm{~g} \mathrm{~kg}^{-1}$ of clay and the following chemical characteristics: $\mathrm{pH}$ in water $=5.22 ; \mathrm{P}$ $($ Mehlich $)=46,08 \mathrm{mg} \mathrm{dm}^{-3} ; \mathrm{K}($ Mehlich $)=0.11$ cmolc $\mathrm{dm}^{-3} ; \mathrm{Ca}^{2^{+}}\left(\mathrm{KCl} 1 \mathrm{~mol} \mathrm{~L}{ }^{-1}\right)=6.37 \mathrm{cmolc}$ $\mathrm{dm}^{-3} ; \mathrm{Mg}^{2^{+}}\left(\mathrm{KCl} 1 \mathrm{~mol} \mathrm{~L}^{-1}\right)=2.05 \mathrm{cmolc} \mathrm{dm}^{-3}$; $\mathrm{H}+\mathrm{Al}\left(\right.$ calcium acetate $\left.0.5 \mathrm{~mol} \mathrm{~L}^{-1}\right)=4.50 \mathrm{cmolc}$ $\mathrm{dm}^{-3} ; \mathrm{CTC}=13.03 \mathrm{cmolc} \mathrm{dm}^{-3}, \mathrm{~V}=65.49 \% ; \mathrm{Cu}=$ $28.48 \mathrm{mg} \mathrm{dm}^{-3} ; \mathrm{Zn}=33.37 \mathrm{mg} \mathrm{dm}^{-3} ; \mathrm{Mn}=226.70$ $\mathrm{mg} \mathrm{dm}{ }^{-3}$; and $\mathrm{Fe}=20.31 \mathrm{mg} \mathrm{dm}^{-3}$.
The Tifton 85 bermudagrass area was planted 10 years ago and is exclusively intended for hay and haylage, and used water waste swine biofertilizer as the sole source of fertilization. This was applied on the surface of the hay and haylage production area by spraying, with coupled equipment, at 7 and 14 days of forage regrowth, averaging $60 \mathrm{~m}^{3} \mathrm{ha}^{-1}$ per application.

The grass was cut on March 22, 2014, at 3:30 p.m., when the Tifton 85 bermudagrass had grown for 60 days, using a conditioning mower with iron-free toe pickers, regulated to cut to 0.04 and $0.08 \mathrm{~m}$ from the ground. Turns were performed 1, 
19 , and $44 \mathrm{~h}$ after cutting. Baling took place on March 24, 2014 at 3:30 p.m., with total drying time in the field of $48 \mathrm{~h}$, and climatic conditions favorable to dehydration.

Rectangular $12 \mathrm{~kg}$ bales were produced and stored in a masonry shed covered with side walls and windows for ventilation. Bales were arranged on wooden pallets to avoid direct contact with the soil for 120 days. Samples were collected on the bale day (time 0 ) and from hay stored in the shed at $30,60,90$, and 120 days of storage. After drying in a forced air circulation oven at $55^{\circ} \mathrm{C}$ for approximately $72 \mathrm{~h}$, the samples were ground in a Willey type mill with a $1 \mathrm{~mm}$ sieve screen and submitted for laboratory procedures, in which the soluble carbohydrate and fractionations of carbohydrate and protein were determined.

The dry matter $(\mathrm{DM})$, crude protein $(\mathrm{CP})$, mineral matter $(\mathrm{MM})$, and ethereal extract (EE) were determined according to AOAC (1990), neutral detergent fiber (NDF) and acid detergent fiber (ADF) according to van Soest, Robertson, and Lewis (1991), and lignin according to the methodology developed by van Soest (1965) with sulfuric acid, as described by Silva and Queiroz (2006). Estimates of the fractions that make up total carbohydrates (TC) were determined according to Sniffen et al. (1992), calculated as follows: TC = $100-(\% \mathrm{CP}+\% \mathrm{EE}+\% \mathrm{MM})$. The fraction of $\mathrm{C}$ was estimated by the equation: $100 *[\mathrm{NDF}(\% \mathrm{DM}) *$ $0.01 *$ Lignin $(\% \mathrm{NDF}) * 2.4] / \mathrm{TC}(\% \mathrm{DM})$ and the fraction $\mathrm{B} 2$ was calculated by the equation: $100 *$ $[\mathrm{NDF}(\% \mathrm{DM})-\mathrm{PIDN}(\% \mathrm{CP}) * 0.01 * \mathrm{CP}(\% \mathrm{DM})-$ $\mathrm{NDF}(\% \mathrm{DM}) * 0.01 *$ Lignin $(\% \mathrm{NDF}) * 2.4] / \mathrm{TC}$ $(\% \mathrm{DM})$, where PIDN represents the neutral detergent insoluble protein. The carbohydrate fractions with high ruminal degradation rates $(\mathrm{A}+$ B1) were determined by the difference between 100 - $(\mathrm{C}+\mathrm{B} 2$ fraction). The determination of soluble carbohydrates was done according to the methodology described by Johnson et al. (1966), with a spectrophotometer reading at a wavelength of $480 \mathrm{~nm}$.

To determine the fractionation of crude protein, the recommendations of Licitra, Hernandez and van Soest (1996) were followed. Fraction A was determined from the treatment of a $0.5 \mathrm{~g}$ sample with $50 \mathrm{~mL}$ of water for $30 \mathrm{~min}$, then adding $10 \mathrm{~mL}$ of trichloroacetic acid (TCA) for another $30 \mathrm{~min}$. Next, the sample was filtered using filter crucibles and the residual nitrogen was measured by the Kjeldahl method. Fraction A was obtained from the difference between total nitrogen content and insoluble nitrogen in TCA.
Total soluble nitrogen was obtained by incubating $0.5 \mathrm{~g}$ of sample with $50 \mathrm{~mL}$ of boratephosphate buffer (BPB) and $1 \mathrm{~mL}$ of $10 \%$ sodium azide. After three hours of incubation, the sample was filtered and the residue analyzed for BPB insoluble nitrogen. The nitrogen soluble in BPB was determined from the difference between the total nitrogen content and the nitrogen insoluble in BPB. The fraction $\mathrm{B} 1$, in turn, was determined from the difference between the nitrogen content soluble in BPB and the soluble nitrogen in TCA. Neutral detergent insoluble nitrogen (NIDN) and acid detergent insoluble nitrogen (NIDA) were measured by the NDF and ADF residues, respectively. Fraction B3 was obtained from the difference between NIDN and NIDA. Fraction C constituted NIDA and fraction B2 was determined from the difference between insoluble nitrogen in BPB and the NIDN. The protein content was obtained by multiplying the nitrogen content by a factor of 6.25 .

The experimental design was a randomized block design with two subdivided plots with two treatments allocated in the plots: 0.04 and $0.08 \mathrm{~m}$ of soil cutting height and five sampling times in the subplots: baling, 30, 60, 90 and 120 days of hay storage each with five replicates.

We analyzed data using analysis of variance in SISVAR 5.0 software (FERREIRA, 2011), and when the $\mathrm{F}$ test result was significant, the variable storage periods $(0,30,60,90$, and 120 days) were assessed using regression analysis, with the choice of the model that presented a minimum significance of 5\% by the Student's t-test, and with a higher coefficient of determination $(\mathrm{R})$.

\section{RESULTS AND DISCUSSION}

The total carbohydrate content (TC) of the Tifton 85 bermudagrass hay responded negative linearly to the storage time at the cutting height at $0.04 \mathrm{~m}$ from the soil, and in a quadratic form with storage time at the cutting height at $0.08 \mathrm{~m}$ from the soil. There was a difference between heights after 60 days of storage (Figure 2). The reduction in TC observed with the increase in hay storage time was related to the higher levels of crude protein and ether extract registered in the hays after 30 days of storage.

The values of TC obtained in the study (between $76.52 \%$ and $80.82 \%$ dry matter) were close to those of van Soest (1994), constituting 50 to $80 \%$ of the dry matter of the forage plants. 


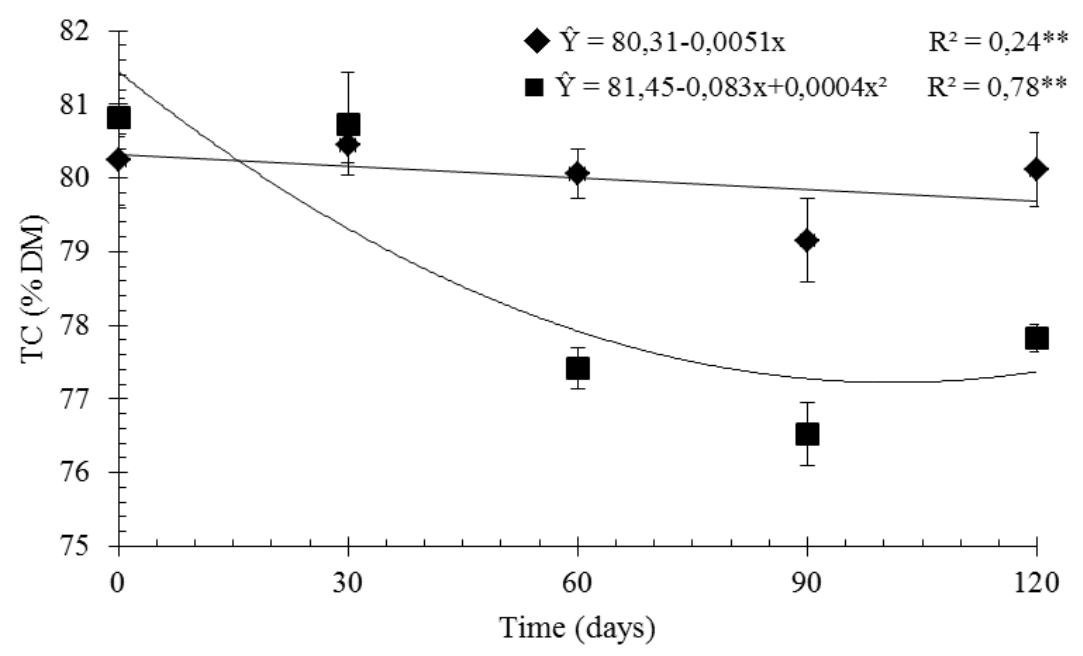

Figure 2. Mean total carbohydrate (TC) percentage in Tifton 85 bermudagrass hay, at the cutting height at 0.04 $\mathrm{m}(\diamond)$ and $0.08 \mathrm{~m}(\boldsymbol{\bullet})$ from the soil in relation to storage time in days.

In tropical grasses, TC represents the highest proportion of dry matter in plants and the variation in the quality of this fraction directly interferes with the availability of energy to the ruminant.

The non-fibrous carbohydrates of the rumen degradation, represented by fraction $\mathrm{A}+\mathrm{B} 1$, responded in a negative linear way to the storage periods evaluated at the two cutting heights (Figure 3 ), with no differences between the heights. The reduction in the $\mathrm{A}+\mathrm{B} 1$ fraction in the hay, cut at heights of $0.04 \mathrm{~m}$ and $0.08 \mathrm{~m}$, was 0.10 and 0.11 percentage points for each storage day, respectively. This decrease can be explained by the age of the forage cutting and the effect of temperature, as high temperatures cause rapid metabolic activity in the plant, and are associated with a decrease in metabolites of the cellular contents and photosynthetic products, which are quickly converted into structural components (VAN SOEST, 1994). Foods with high fraction A + B1 are a good energy source for increasing the content of ruminal microorganisms that use non-fiber carbohydrates (CARVALHO et al., 2007) and for the synchronism between the digestive rate of proteins and carbohydrates, which may have an important effect on the final products of fermentation and animal production (NOCEK; RUSSELL, 1988).

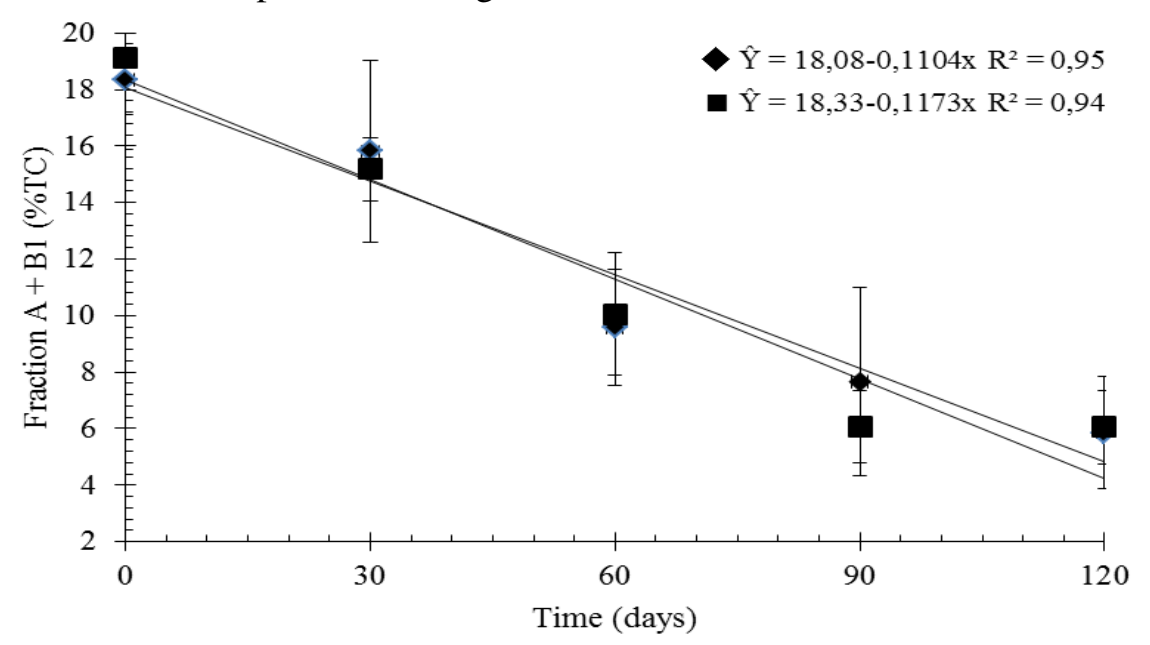

Figure 3. Mean percentage of non-fibrous carbohydrates $(\mathrm{A}+\mathrm{B} 1)$ of Tifton 85 bermudagrass hay at a cutting height of $0.04 \mathrm{~m}$ and $0.08 \mathrm{~m}$ in relation to storage time in days.

The levels of fraction B2 ranged between 74.06 and $87.21 \%$ TC, and exhibited a positive linear response as a function of the storage time, for a cutting height of $0.04 \mathrm{~m}$ above soil level, and quadratic behavior for a cutting height of $0.08 \mathrm{~m}$ above soil level (Figure 4). Differing between the cutting heights only at 90 days of storage. This increase in the values obtained for the B2 fractions 
during hay storage can be explained by the high NDF content, with a mean of $703.73 \mathrm{~kg} \mathrm{ha}^{-1}$ and
$812.08 \mathrm{~kg} \mathrm{ha}^{-1}$ at the baling and after 120 days of storage, respectively.

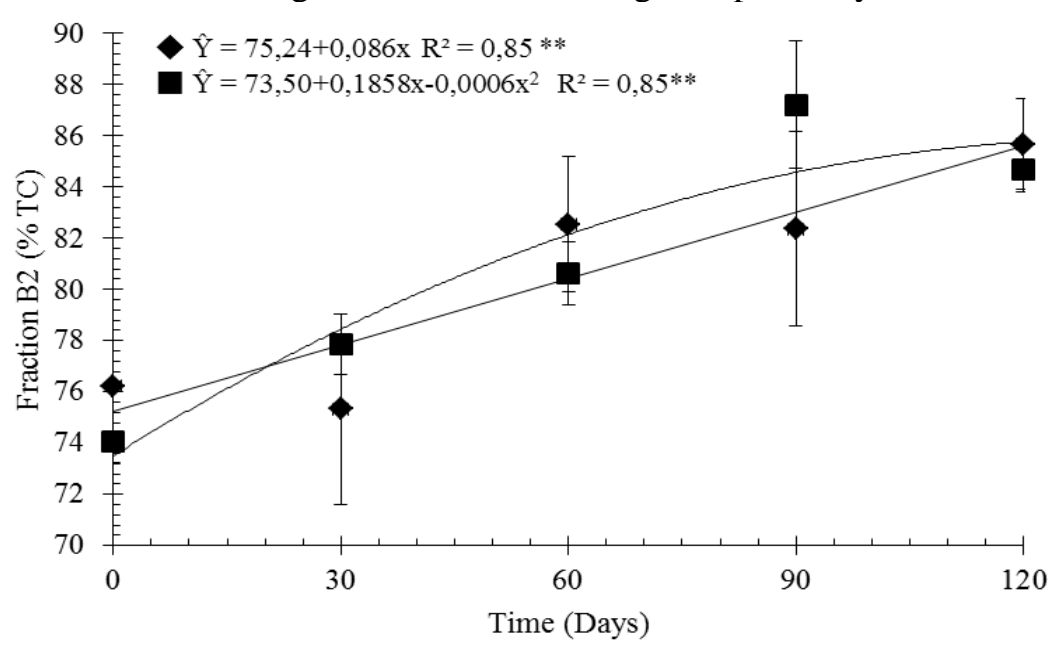

Figure 4. Mean percentage content of available components corresponding to the potentially degradable fraction (B2) of Tifton 85 bermudagrass hay, at a cutting height of $0.04 \mathrm{~m}(\bullet)$ and $0.08 \mathrm{~m}(\mathbf{\bullet})$ in relation to storage time in days.

Bulk foods with higher NDF content have a higher proportion of the carbohydrate fraction $\mathrm{B} 2$. Because it provides energy in the rumen more slowly, it can affect the efficiency of microbial synthesis and animal performance. In addition, consumption may be limited by a high indigestible fraction (fraction $\mathrm{C}$ ) of fodder. Thus, forage must be supplemented with energy sources that are readily available in the rumen, when there is no protein limitation in quantity and quality. The results obtained in this study differ with those of Souza et al. (2012), which consisted of mean values of $57.62 \%$ TC for hay of four cassava varieties. Although fraction B2 is potentially digestible,
Russell et al. (1992) emphasized that carbohydrates rich in fraction B2 require non-protein nitrogen to meet the nitrogen requirements of microorganisms fermenting structural carbohydrates.

A proportion of indigestible carbohydrates of the cell wall (fraction C) of the Tifton 85 bermudagrass hay responded linearly to the storage time at the cutting height of $0.08 \mathrm{~m}$ from the soil, with a fractional increase of 0.02 percentage points per storage day, and in a quadratic form to storage time at the cutting height of $0.04 \mathrm{~m}$ from the soil. There was a difference between the heights at 90 and 120 days of storage (Figure 5). The levels of fraction $\mathrm{C}$ were between 5.42 and $9.97 \%$ TC.

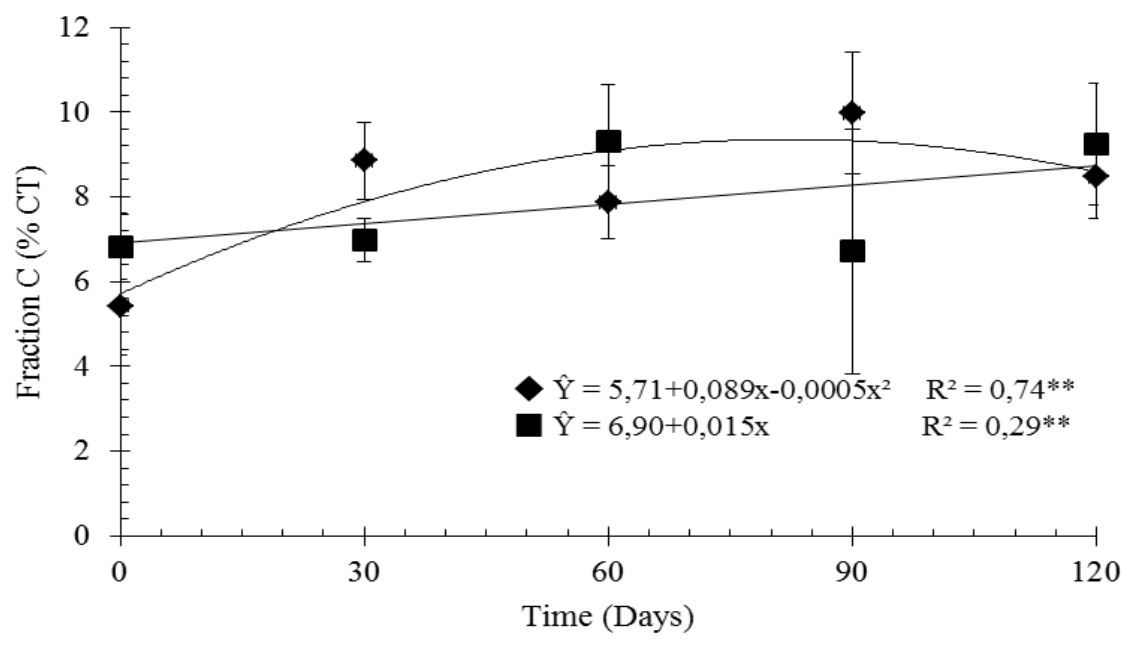

Figure 5. Mean percentages of the indigestible fraction of the cell wall (C) of the Tifton 85 bermudagrass hay, at a cutting height of $0.04 \mathrm{~m}(\bullet)$ and $0.08 \mathrm{~m}(\mathbf{-})$ in relation to storage time in days. 
The variation in the values of fraction $\mathrm{C}$ is related to the lignin content present in the plant, which confers important differences because it is the basis for higher or lower digestibility of the fibrous carbohydrates (MELLO et al., 2006). The increase in fraction $\mathrm{C}$ and the reduction of the $\mathrm{A}+\mathrm{B} 1$ fractions, implies a reduction in energy availability for the microorganisms that ferment fibrous and non-fibrous carbohydrates, which may limit the efficiency of microbial protein synthesis and additionally lead to nitrogen losses in the rumen, if protein supplements of medium or rapid degradation are used (SILVA; SILVA, 2013). These results were lower than those obtained by Ribeiro et al. (2001), who evaluated Tifton 85 bermudagrass hay at different regrowth ages and found indigestible carbohydrate values of 13.59 and $17.87 \%$ TC for hay with 28 and 56 days of regrowth, respectively.

The soluble carbohydrate (CS) concentration of the Tifton 85 bermudagrass hay responded in a quadratic manner to the storage time, for cutting heights of 0.04 and $0.08 \mathrm{~m}$ above soil level; minimum values of 11.53 and $10.70 \mathrm{~g} \mathrm{~kg}^{-1}$ of
DM were estimated at 93.44 and 91.16 days of storage, respectively (Figure 6). There was no difference between heights. The values found for this variable in the present study were lower than those found by Ribeiro et al. (2001), who when evaluating Tifton 85 bermudagrass at different cutting ages, found a mean of $40.36 \mathrm{~g} \mathrm{~kg}^{-1} \mathrm{DM}$, where as in the present the mean at the time of baling was $26.44 \mathrm{~g} \mathrm{~kg}^{-1} \mathrm{DM}$. Our values are considered low, but common for tropical grasses that are naturally low in soluble carbohydrates. Morgado et al. (2009), evaluated different feed sources for horses when estimating CS levels of Coast-Cross grass and also found higher values of $41.00 \mathrm{~g} \mathrm{~kg}^{-1} \mathrm{DM}$.

The decrease in the levels of soluble carbohydrates was expected because during the process of dehydration of plants, cellular respiration occurs and causes the consumption of these carbohydrates. Changes in the concentrations of these can also occur during storage, because the action of microorganisms and moistening of the hay can lead to a reduction of the contents.

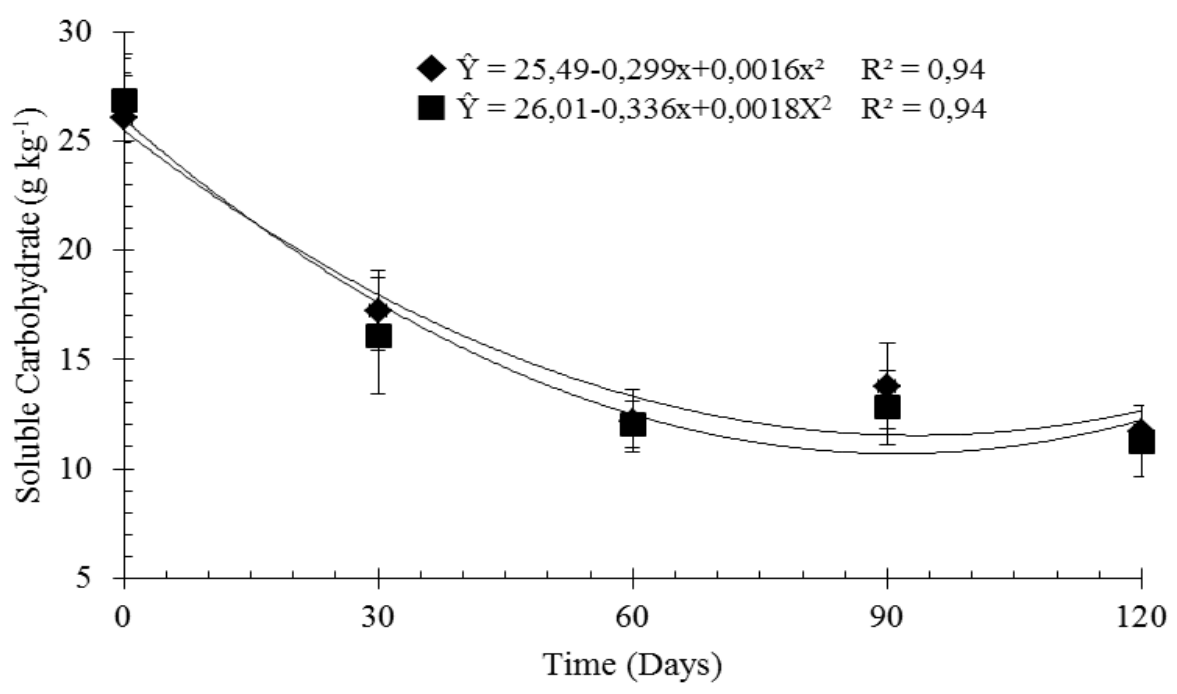

Figure 6. Soluble carbohydrate concentration of Tifton 85 bermudagrass hay at the cutting height of $0.04 \mathrm{~m}$ and $0.08 \mathrm{~m}$ in relation to storage time in days.

The non-protein nitrogen (NNP), represented by fraction $\mathrm{A}$, presented quadratic behavior over the storage time evaluated, at a cutting height at $0.08 \mathrm{~m}$ above soil level and a positive linear relationship for cutting heights at $0.04 \mathrm{~m}$ above soil level (Figure 7). Differences were detected between heights only at 90 days of storage. Low levels of fraction A at 30 days of storage can be attributed to the high levels of dry matter recorded in hays (mean of $876.62 \mathrm{~kg} \mathrm{ha}^{-1}$ ), an indication of the occurrence of less proteolysis during storage. The main alteration in the chemical composition of hay occurs in the first 30 days of storage, which may have affected the A fraction (CASTAGNARA et al., 2011).

Nunes Irmão et al. (2008), working with hay from the upper third of cassava shoots harvested eight months after planting obtained a value of $36.89 \% \mathrm{CP}$ for fraction $\mathrm{A}$, which was higher than that found in the present study. According to Russell et al. (1992), the sources of NNP are fundamental for good ruminal functioning because the fermentative ruminal microorganisms of carbohydrates preferentially use ammonia as a 
source of nitrogen. However, the high proportion of fraction A will promote large losses of nitrogen through ammonia, which can be recycled to the rumen; however, a part must be metabolized and removed from the body. This process has an energy expenditure that is known as the cost of urea (OWENS, ZINN, 1988). The higher the values of protein fractions $\mathrm{A}$ and $\mathrm{B} 1$, the greater the need to supply rapidly degrading carbohydrates to obtain an adequate synchronism in the fermentation of carbohydrates and proteins in the rumen, which leads to better animal performance (RIBEIRO et al., 2001).

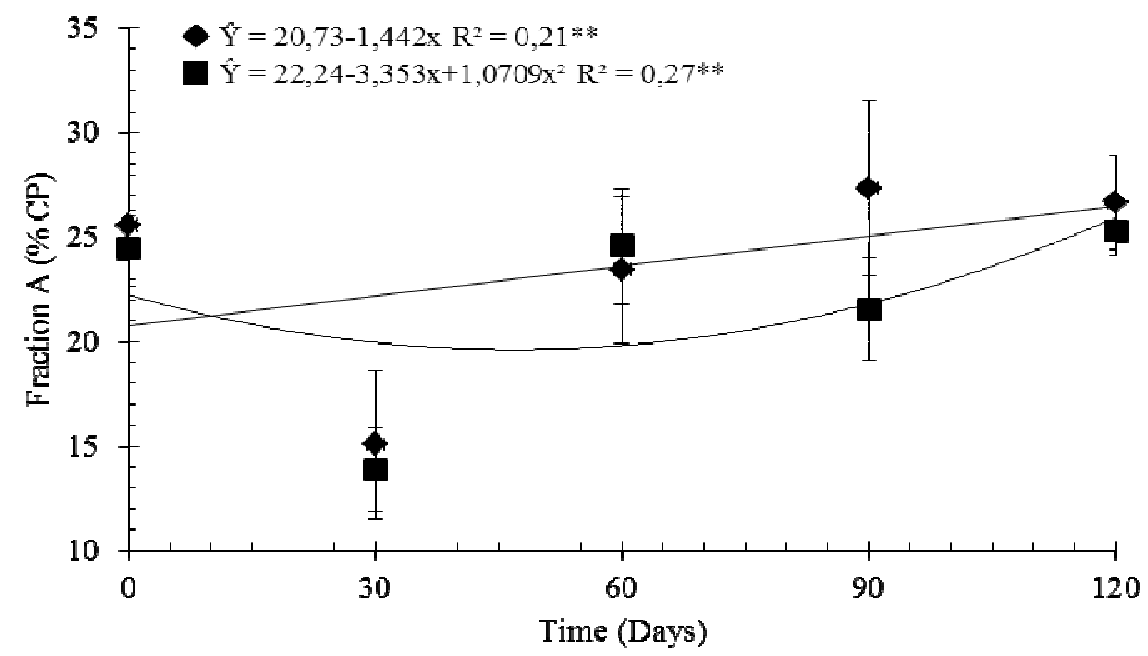

Figure 7. Percentage values of protein fraction A of hay of Tifton 85 bermudagrass at cutting heights of $0.04 \mathrm{~m}$ $(\checkmark)$ and $0.08 \mathrm{~m}(\mathbf{-})$ in relation to storage time in days.

The proportion of soluble proteins, rapidly degradable in the rumen (fraction B1), presented quadratic behavior for $0.04 \mathrm{~m}$ cutting heights and a positive linear behavior for a cutting height of 0.08 $\mathrm{m}$, and did not differ between the heights (Figure 8).
According to Balsalobre et al. (2003), the B1 fraction is of little importance in forage grasses because it normally represents values lower than $10 \%$ of total crude protein.

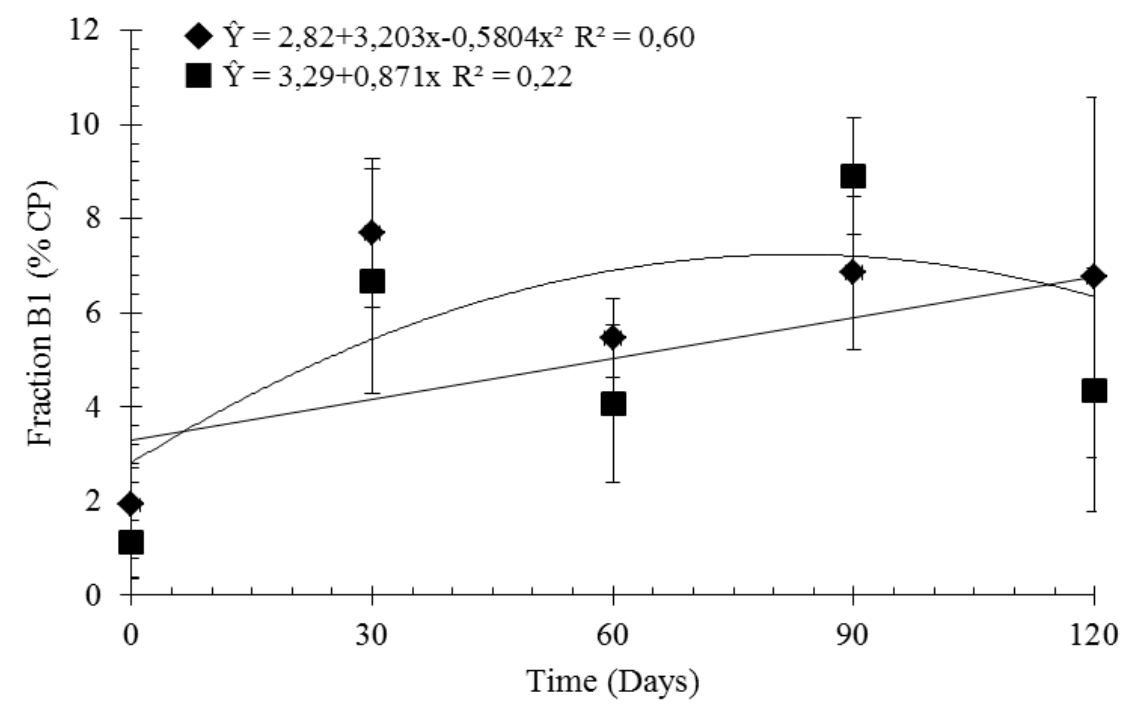

Figure 8. Percentage values of the B1 protein fraction of Tifton 85 bermudagrass hay at cutting heights of 0.04 $\mathrm{m}$ and $0.08 \mathrm{~m}$ in relation to storage time in days.

Because of the rapid rumen degradation rate relative to the $\mathrm{B} 3$ fraction, fraction $\mathrm{B} 1$ tends to be extensively degraded in the rumen, contributing to the $\mathrm{N}$ requirements of the microorganisms of this compartment (SNIFFEN et al., 1992).

The values of insoluble protein, with intermediate degradation rates (fraction B2), 
exhibited a negative linear response as a function of the storage time, with a reduction of the fraction of 0.09 and 0.11 percentage units for each day of storage, for a hay cut 0.04 and $0.08 \mathrm{~m}$ above soil level, respectively, and did not differ between the cutting heights (Figure 9).

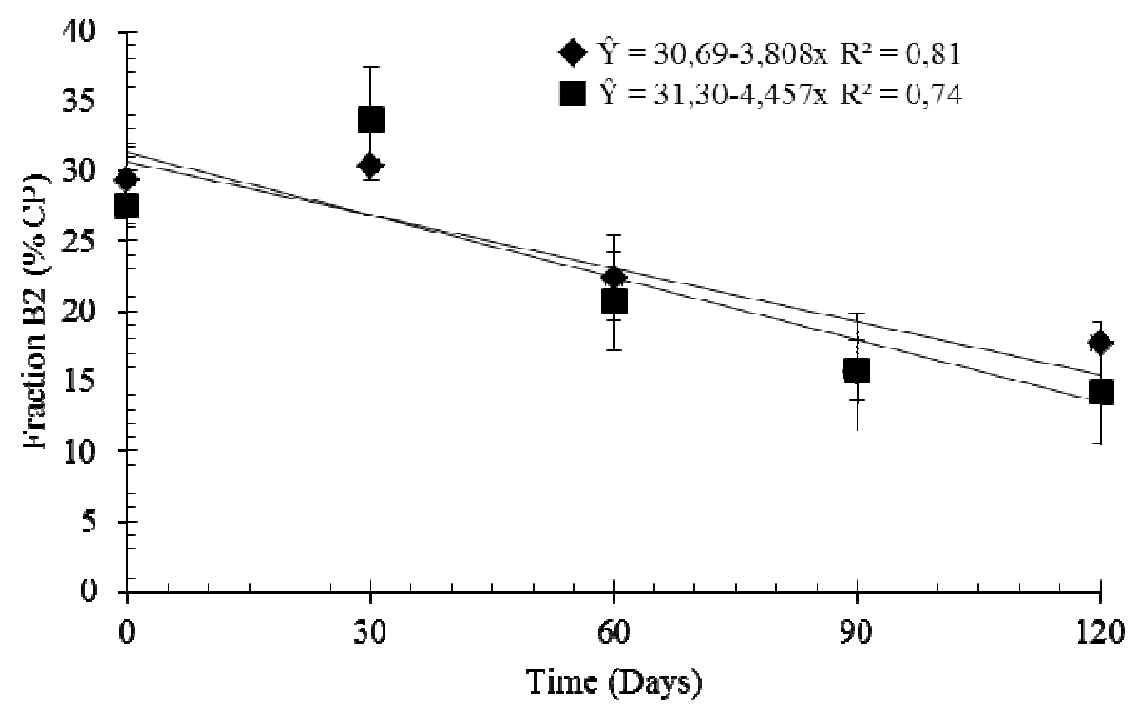

Figure 9. Percentage values of the protein fraction B2 of hay of Tifton 85 bermudagrass at a cutting height of $0.04 \mathrm{~m}$ and $0.08 \mathrm{~m}$ in relation to storage time in days.

The insoluble protein content with slow degradation rate, represented by the fraction B3, exhibited quadratic behavior during the storage period evaluated, for the two cutting heights, but values did not differ between cutting heights (Figure
10). The values in the present study were similar to those obtained by Sá et al. (2010), who found the average value of $32.7 \% \mathrm{CP}$ for the nitrogenous fraction $\mathrm{B} 3$ in Tifton bermudagrass 85 .

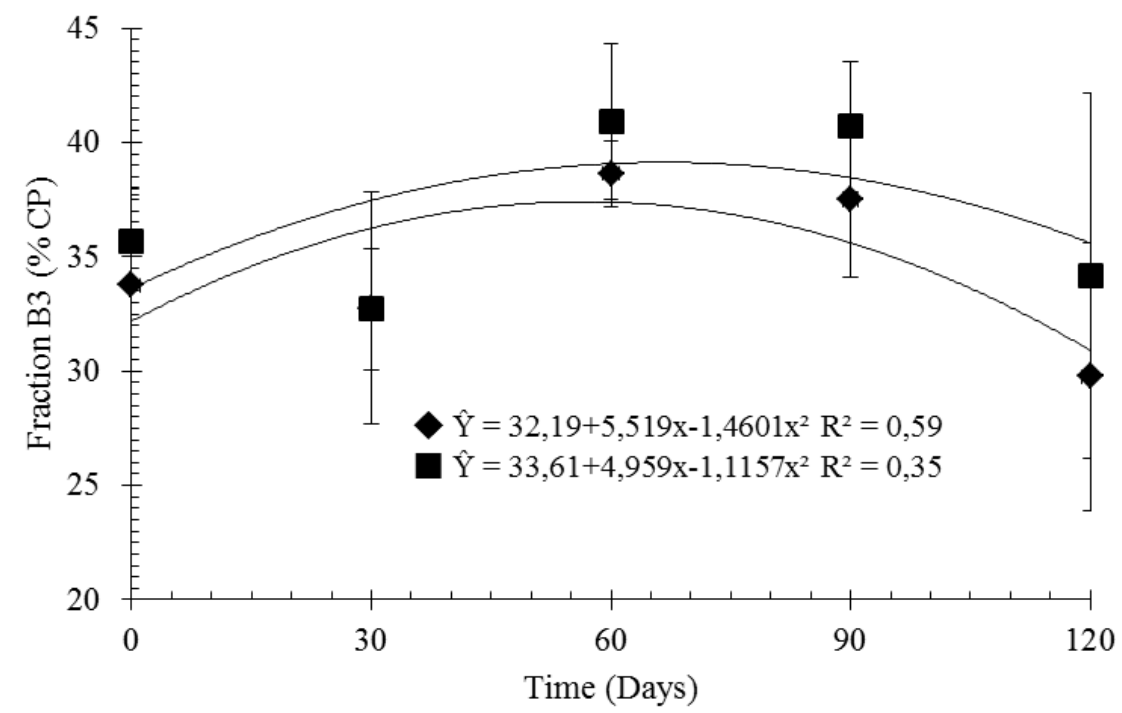

Figure 10. Percentage values of the $\mathrm{B} 3$ protein fraction of Tifton 85bermudagrass hay at cutting heights of $0.04 \mathrm{~m}$ and $0.08 \mathrm{~m}$ in relation to storage time in days.

The protein fraction B3 constituted approximately $1 / 3$ of the crude protein of the hay and presented lower digestion rates, which would consequently cause greater leakage into the intestines (RIBEIRO et al., 2001).

The proportion of insoluble non-digestible proteins in the rumen and intestines (fraction $\mathrm{C}$ ) exhibited quadratic for $0.08 \mathrm{~m}$ cutting height and a positive linear relationship for cutting heights of $0.04 \mathrm{~m}$ above soil level (Figure 11). There was no difference between the heights with values ranging from 9.36 to $21.94 \% \mathrm{CP}$. This shows that an expressive protein portion from hay is used for microbial growth or even as a true protein source in 
the post-ruminal digestive tract. According to van Soest (1994), 5 to $15 \%$ of the total nitrogen in the fodder is connected to lignin and is completely unavailable. The values found were above the range considered ideal.

Fraction $\mathrm{C}$ corresponds to unavailable nitrogen, and consists of proteins and nitrogen compounds associated with lignin, tannin-protein complexes, and Maillard products, which are highly resistant to the attack of enzymes of microbial and host origin (SNIFFEN et al., 1992; VAN SOEST, 1994).

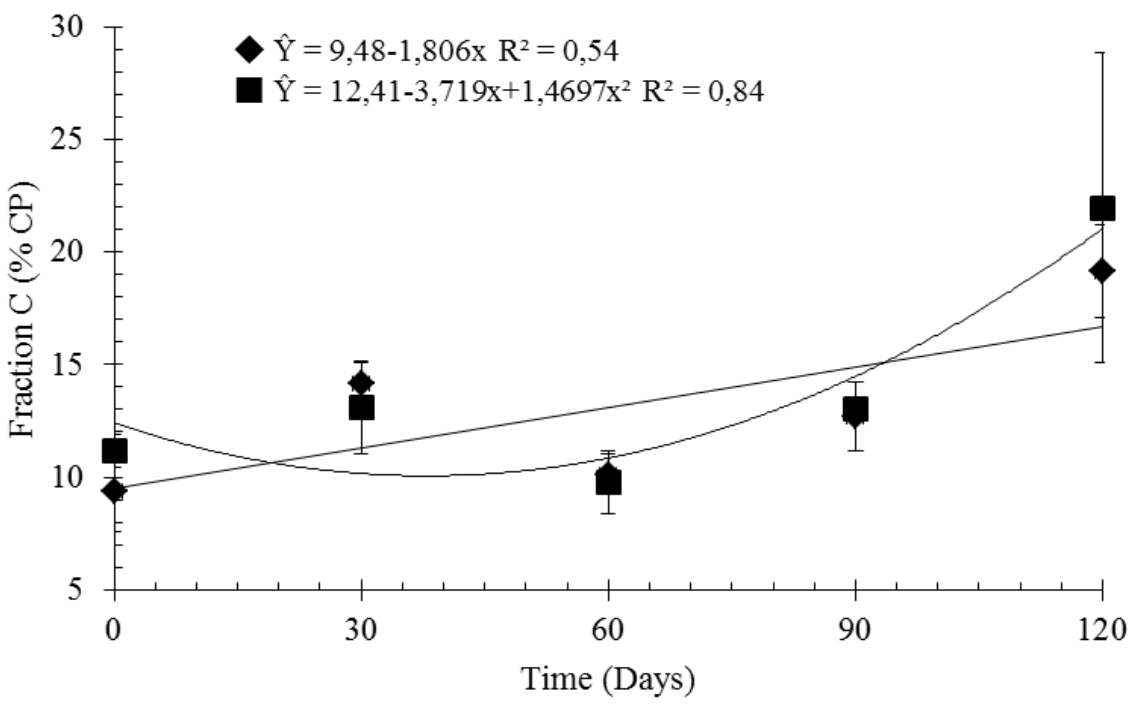

Figure 11. Percentage values of the protein fraction $\mathrm{C}$ of Tifton 85 bermudagrass hay at cutting heights of 0.04 $\mathrm{m}$ and $0.08 \mathrm{~m}$ in relation to storage time in days.

\section{CONCLUSION}

It is recommended the cutting of the Tifton 85 bermudagrass forage to produce hay at $8 \mathrm{~cm}$ and its storage up to 30 days provided that under ideal conditions.

RESUMO: Este trabalho objetivou avaliar o fracionamento de carboidratos e proteína do feno de capim Tifton 85 sob duas alturas de corte em relação ao nível do solo $(0.04$ e $0.08 \mathrm{~m})$, durante 120 dias de armazenamento. Foram coletadas amostras no enfardamento e no feno armazenado em galpão aos 30, 60, 90 e 120 dias de armazenamento. Após foram submetidas a procedimentos laboratoriais, onde foram determinados os teores de carboidratos solúveis, fracionamento de carboidrato e fracionamento de proteína. Os resultados foram estudados sob o delineamento em blocos casualizados com parcelas subdivididas no tempo com 2 tratamentos alocados nas parcelas: altura de corte de 0.04 e 0.08 m do solo e cinco tempos nas subparcelas: enfardamento, 30, 60, 90 e 120 dias de armazenamento do feno, com cinco repetições. A concentração de carboidratos solúveis respondeu de forma quadrática ao tempo de armazenamento, para altura de corte de 0.04 e $0.08 \mathrm{~m}$ do solo, estimando-se valores de mínima de 11.53 e $10.70 \mathrm{~g} \mathrm{~kg}^{-1}$ de MS aos 93.44 e 91.16 dias de armazenamento, respectivamente. A fração de carboidrato A + B1, respondeu de forma linear negativa aos períodos de armazenamento avaliados nas duas alturas de corte, não diferindo entre as alturas. Os teores da fração de carboidratos B2 e de proteína A e C apresentaram resposta linear positiva em função do tempo de armazenamento para altura de corte a $0.04 \mathrm{~m}$ e efeito quadrático para altura de corte do feno a $0.08 \mathrm{~m}$ do solo, sendo observado comportamento inverso em ambas as alturas de corte para os teores protéicos B1 e de carboidratos fração C. A fração proteica B2 apresentou resposta linear negativa em função do tempo de armazenamento, com redução da fração de 0,09 e 0,11 unidades percentuais a cada dia de armazenamento, para altura de corte do feno a 0.04 e $0.08 \mathrm{~m}$, respectivamente. A fração B3 respondeu de forma quadrática ao tempo de armazenamento, nas duas alturas de corte estudadas. O armazenamento do feno de capim Tifton 85 cortado a $0.04 \mathrm{~m}$ de altura do solo, durante 120 dias, ocasiona diminuição das frações de rápida degradação ruminal e aumento da fração indigestível, nos fracionamentos de carboidratos e de proteína. Recomenda-se o corte da forrageira Tifton 85 para produção de feno a $0.08 \mathrm{~m}$ e seu armazenamento até 30 dias em condições ideais.

PALAVRAS-CHAVE: Conservação de forragem. Fenação. Compostos nitrogenados. Amido. 


\section{REFERENCES}

ASSOTIATION OF OFFICIAL ANALYTICAL CHEMISTS - AOAC. 1990. Official methods of analysis. 15.ed., Virginia: Arlington. 1117 p.

BALSALOBRE, M. A. A.; CORSI, M.; SANTOS, P. M.; VIEIRA, I.; CÁRDENAS, R. R. Composição química e fracionamento do nitrogênio e dos carboidratos do capim-tanzânia irrigado sob três níveis de resíduo pós-pastejo. Revista Brasileira de Zootecnia, Viçosa, v. 32, n. 3, p. 519-528, 2003. https://doi.org/S151635982003000300003

CARVALHO, G. G. P.; GARCIA, R.; PIRES, A. J. V.; PEREIRA, O. G.; FERNANDES, F. E. P.; OBEID, J. A.; CARVALHO, B. M. A. Fracionamento de carboidratos de silagem de capim-elefante emurchecido ou com farelo de cacau. Revista Brasileira de Zootecnia, Viçosa, v. 36, n. 4, p. 1000-1005, 2007.

https://doi.org/S1516-35982007000500003

CASTAGNARA, D. D.; AMES, J. P.; NERES, M. A.; OLIVEIRA, P. S. R.; SILVA, F. B.; MESQUITA, E. E.; STANGARLIN, J. R.; FRANZENER, G. Use of conditioners in the production of Tifton 85 grass hay. Revista Brasileira de Zootecnia, Viçosa, v. 40, n. 10, p. 2083-2090, 2011. https://dx.doi.org/10.1590/S151635982011001000003

EMPRESA BRASILEIRA DE PESQUISA AGROPECUÁRIA - EMBRAPA. Centro Nacional de Pesquisa de Solos. Sistema brasileiro de classificação de solos. Rio de Janeiro, 2013.

FERREIRA, D. F. Sisvar: a computer statistical analysis system. Ciência e Agrotecnologia, Lavras, v. 35, n. 6, p. 1039-1042, 2011. https://dx.doi.org/10.1590/S1413-70542011000600001

JOHNSON, R. R.; BALWANI, T. L.; JOHNSON, L. J.; McCLURE, E. K.; DEHORITY, B. A. Corn plant maturity. II. Effect on in vitro cellulose digestibility and soluble carbohydrate content. Journal of Animal Science, Champaign, v. 25, n. 3, p. 617-623, 1966. https://doi.org/10.2527/jas1966.253617x

LICITRA, G.; HERNANDEZ, T. M.; VAN SOEST, P. J. Standardization of procedures for nitrogen fractionation of ruminant feeds. Animal Feed Science and Technology, Pittsburgh, v. 57, n. 4, p. 347-358, 1996. https://doi.org/10.1016/0377-8401(95)00837-3

MELLO, S. Q. S.; FRAÇA, A. F. S.; LIMA, M. L. M.; RIBEIRO, D. S.; MIYAGI, E. S.; REIS, J. G. Parâmetros do valor nutritivo de nove variedades de cana-de-açúcar cultivadas sob irrigação. Ciência Animal Brasileira, Goiás, v. 7, n. 4, p. 373-380, 2006.

MORGADO, E. S.; ALMEIDA, F. Q.; SILVA, V. P.; GOMES, A. V. C.; GALZERANO, L.; VENTURA, H. T.; RODRGUES, L. M. Digestão dos carboidratos de alimentos volumosos em equinos. Revista Brasileira de Zootecnia, Viçosa, v. 38, n. 1, p. 75-81, 2009. https://dx.doi.org/10.1590/S1516-35982009000100010

NOCEK, J.; RUSSELL, J. B. Protein and carbohydrate as an integrated system. Relationship of ruminal availability to microbial contribuition and milk production. Journal of Dairy Science, Champaign, v. 71, n. 8, p. 2070-2107, 1988.

NUNES IRMÃO, J.; FIGUEIREDO, M. P.; PEREIRA, L. G. R.; FERREIRA, J. Q.; RECH, J. L.; OLIVEIRA, B. M. Composição química do feno da parte aérea da mandioca em diferentes idades de corte. Revista Brasileira de Saúde e Produção Animal, Salvador, v. 9, n. 1, p. 158-169, 2008.

OWENS, F. N.; ZINN, R. Protein metabolism of ruminant animals. In: CHURCH, D.C. (Ed.) The ruminant animal, digestive physiology and nutrition. Englewood Cliffs: Prentice Hall, 1988. p. 227-249. 
PASQUALOTO, M.; NERES, M. A.; GUIMARÃES, V. F.; KLEIN, J.; INAGAKI, A. M.; DUCATI, C. Gas Exchanges and Dehydration in Different Intensities of Conditioning in Tifton 85 Bermudagrass: Nutritional Value during Hay Storage. Asian-Australasian Journal of Animal Sciences, v. 28, n. 6, p. 807-815, 2015. https://doi.org/10.5713/ajas.14.0826

PEREIRA, E. S.; ARRUDA, A. M. V.; MIZUBUTI, I. Y.; CAVALCANTE, M. A. B.; RIBEIRO, E. L. A.; OLIVEIRA, S. M. P.; RAMOS, B. M. O.; COSTA, J. B. Frações nitrogenadas e de carboidratos e cinética ruminal da matéria seca e fibra em detergente neutro de silagens de Tifton 85 (Cynodon spp.). Semina: Ciências Agrárias, Londrina, v. 28, n. 3, p. 521-528, 2007. https://dx.doi.org/10.5433/16790359.2007v28n3p521

RIBEIRO, G. K.; PEREIRA, O. G.; VALADARES FILHO, R. G.; CABRAL, L. S. Caracterização das frações que constituem as proteínas e os carboidratos, e respectivas taxas de digestão, do feno de Capim-Tifton 85 de diferentes idades de rebrota. Revista Brasileira de Zootecnia, Viçosa, v. 30, n. 2, p. 589-595, 2001. https://dx.doi.org/10.1590/S1516-35982001000200039.

RUSSEL, J. B.; O'CONNOR, J. D.; FOX, D. G.; VAN SOEST, P. J.; SNIFFEN, C. J. A net carbohydrate and protein system for evaluating cattle diets: I. Rumen fermentation. Journal of Animal Science, Champaign, v. 70, n. 11, p. 3551-3561, 1992. https://doi.org/10.2527/1992.70113551x

SÁ, J.F.; PEDREIRA, M. S.; SILVA, F. F.; BONOMO, P.; FIGUEIREDO, M. P.; MENEZES, D. R.; ALMEIDA, T. B.Fracionamento de carboidratos e proteínas de gramíneas tropicais cortadas em três idades. Arquivo Brasileiro de Medicina Veterinária e Zootecnia, Belo Horizonte, v. 62, n. 3, p. 667-676, 2010. https://dx.doi.org/10.1590/S0102-09352010000300023

SILVA, D. J.; QUEIROZ, A. C. Análise de alimentos: métodos químicos e biológicos. Viçosa: UFV, 2006, $235 \mathrm{p}$.

SILVA, S. P.; SILVA, M. M. C. Fracionamento de carboidrato e proteína segundo o sistema CNCPS. Veterinária Notícias, Uberlândia, v. 19, n. 2, p. 95-108, 2013.

SNIFFEN, C. J.; O'CONNOR, J. D.; VAN SOEST, P. J.; FOX, D. G.; RUSSELL, J. B. A net carbohydrate and protein system for evaluating cattle diets: II. Carbohydrate and protein availability. Journal of Animal Science, Champaign, v. 70, n. 11, p. 3562-3577, 1992. https://dx.doi.org/10.2527/1992.70113562x

SOIL SURVEY STAFF. Keys to soil taxonomy. 10th ed. Washington, DC: USDA-Natural Resources Conservation Service, 2010.

SOUZA, A. S.; ROCHA JÚNIOR, V. R.; MOTA, A. D.S.; ROCHA, W. J. B.; OLIVEIRA, C. R.; AGUIAR, A. C. R.; SANTOS, C. C. R.; MENDES, G. A. Potencial forrageiro e valor nutricional do feno de diferentes frações da parte aérea de quatro variedades de mandioca. Revista Brasileira de Saúde e Produção Animal, Salvador, v. 13, n. 3, p. 604-618, 2012. https://dx.doi.org/10.1590/S1519-99402012000300002.

VAN SOEST, P. J. Nutritional ecology of the ruminant. 2.ed. New York: Cornell University Press, 1994. 476p.

VAN SOEST, P. J. Symposium on factors influencing the voluntary intake of herbage by ruminants: voluntary intake relation to chemical composition and digestibility. Journal of Animal Science, Champaign, v. 24, n. 3, p. 834-844, 1965. https://dx.doi.org/10.2527/jas1965.243834x

VAN SOEST, P. J.; ROBERTSON, J. B.; LEWIS, B. A. Methods for dietary fiber, neutral detergent fiber and non-starch polysaccharides in relation to animal nutrition. Journal of Dairy Science, Champaign, v. 74, p. 3583-3597, 1991. https://doi.org/10.3168/jds.S0022-0302(91)785512 